\title{
Pragmatic Relevance Theories in Interpreting Indonesian Covid-19 Memes
}

\author{
Romadhon*, Ahmad Bukhori Muslim \\ English Language Study Program, Universitas Pendidikan Indonesia, Bandung \\ *Corresponding author. Email: romadhon@upi.edu
}

\begin{abstract}
Internet memes are widely used as a way to respond and express issues related to Covid-19. However, the interpretation of memes comprehensively involving contextual events and theoretical frameworks to make meaning potential is not common among users. This study was conducted to investigate Pragmatic implication using relevance theory on five memes related to some Covid-19 issues taken from social media purposively. The data were analyzed and interpreted following several categories: multimodality proposed by McCloud, verbal implicature and explicature based on Yus, visual implicature and explicature coined by Forceville, and humor theory of Catanescu and Tom, and Yus. The researcher employed a qualitative descriptive to capture social phenomenon naturally. This study revealed that using contextual event and theoretical approaches in analyzing memes make the interpretation relevant and comprehensive. This study is significant for giving users a reference and content creators to interpret and produce relevant memes.
\end{abstract}

Keywords: Interpretation, Indonesian memes, relevance theories

\section{INTRODUCTION}

Since the pandemic of Covid-19, Indonesians should adjust to new normal in daily life such as selfquarantine, work from home, online class, online graduation, and so forth. They express their feeling and respond to Covid-19 issues on social media through memes. As a result, a variety of memes about Covid-19 appear and rise dramatically grasp internet citizen' (netizen). Most of their responses are about disappointment, offense, and critique presented on memes. On the other side, in the middle chaotic of Covid-19, memes give users entertainment because of containing humor. This study was conducted to investigate Pragmatic implication using relevance theory on five memes related to Covid-19 issues taken from social media.

Memes contain a picture and short information to express someone's feeling towards a situation, which also have a humor effect (Taecharungroj \& Nueangjamnong, 2014) to entertain the readers. Moreover, what is written explicitly on memes tells implied meaning intended by the creators. Therefore, people commonly use memes to critique or even offense particular institutions, mostly the government. Memes are widely used, produced, and accessed on the internet and become internet memes (Yus, 2018).

Dawkins 1976 (as stated by Yus, 2018) proposed the term meme referring to a disseminated cultural unit. It means that memes not only transfer information, but also mental users' representation and cultural instructions. According to Dynel (2016), a meme is an artifact on the internet created by anyone by imitating, remixing, and diffusing through technology-mediated communication. Yus (2011) mentioned one of the meme families which is a macro image meme. This meme shows a text-picture combination with the picture in the middle and texts on the top and button. The combination of text and pictures leads to multimodality communication (Forceville, 2014), which also have pragmatic implications (Yus, 2018). The interpretation of memes needs to be relevant to the users' inferential hypotheses (Yus, 2018). Further, the text-picture combination brings cognitive and mental effects due to eventual relevance.

The studies of relevance theory have been conducted widely in social phenomenon primarily related to humor in memes (Forceville, 2014; Lynda \& Idegbekwe, 2020; Segev, Nissenbaum, Stolero, \& Shifman, 2015 Taecharungroj \& Nueangjamnong, 2014). As a response 
to the global phenomenon, memes related to Covid19 issues have considerable numbers being produced. However, the interpretation of memes underlining the contextual events and theoretical approaches to encode memes comprehensively is barely done by users. Hence, inappropriate ways of interpretation can cause memes irrelevant. This study is concerned to interpret Covid-19 Indonesian image macro memes by analyzing the categories of Pragmatic relevance theory. The researcher preferred to focus on Indonesian memes because the eventual context of memes can be observed.

\section{LITERATURE REVIEW}

This study was conducted based on pragmatic relevance theories which include meme, multimodality, and humor. These theories are relavant to interpret the meaning what is implicitly and explicitly showed on Covid-19 memes.

\subsection{Relevance Theory}

Relevance theory was coined by the French scholar Dan Sperber and the British scholar Deirdre Wilson. Sperber and Wilson argue that the key to explaining human communication lies in the notion of relevance, grounded in a general view of human cognition. The central thesis of the theory is that the human cognitive system works in such a way as to tend to maximize relevance concerning communication (Blakemore, 1992; Huang, 2012; Wilson \& Sperber, 2004).

Further, Sperber and Wilson (1986) state that humans tend to pay attention to the most relevant phenomena available; to develop the most relevant possible representations and process them in a context that maximizes their relevance. Relevance, and the maximization of relevance, are the keys to human cognition. Sperber and Wilson claim that information is relevant if it interacts in a certain way with existing human assumptions about the world, which further is called a contextual effect (Blakemore, 1992; Wilson \& Sperber, 2004). In Sperber \& Wilson's (1986) relevance theory lies the notion of two principles: a cognitive principle of relevance and a communicative principle of relevance.

\subsubsection{The Principles of Relevance}

In a cognitive principle, Sperber and Wilson explained that relevance is a function of two factors: cognitive effects and processing effort. The first factor is the outcome of assumptions that already existed in the human cognitive system. An existing assumption is a form of human expectation to derive a new assumption (Blakemore, 1992). The second, effort a cognitive system must expend to yield a satisfactory interpretation of any incoming information processed. Viewed this way, relevance is a matter of degree. The degree of relevance of an input to an individual is a balance between cognitive effects and processing effort: the more cognitive effects achieved, the more relevant input is, the more mental effort takes to process, the less relevant an input is (Allott, 2013).

In the communicative principle, Sperber and Wilson (1986), divided communication theories into two: the code model and the inferential model. Code model refers to any communication that is established by encoding and decoding messages. This model leads more to verbal utterance. Meanwhile, the inferential model based on Grice's theory is a matter of intention. Communication will be achieved by expressing and recognizing intentions, even though Sperber and Wilson (1986) emphasize the inferential model to gain optimal relevance.

Thus, the procedures based on optimal relevance: follow a path of least effort in cognitive computing effects such as testing interpretative hypotheses (disambiguation, reference resolution, implicatures, etc.) in order of accessibility: and stop when the expectations of relevance are satisfied or abandoned.

One of the critical differences between relevance theory and Grice's approach lies in how relevance theory sees the distinction between explicit and implicit communication (Clark, 2013). The distinction between 'what is said' and 'what is implicated' in relevance theory becomes explicature and implicature.

\subsubsection{Explicature and Implicature}

According to Grice (explained by Huang, 2012), explicature is explicit content that refers to any structure or form that is stated or written explicitly without involving any assumption. On other hand, in relevance theory, an explicature is an inferential development of incomplete conceptual representations or logical forms encoded by an utterance. In other words, an explicature is an enrichment of an original utterance to a fully elaborated proportional form (Grundy, 2013; Huang, 2012).

Implicature or implicit content defines as a communicated assumption or proposition that lies in a human's intention. Hence, to understand implicature, recovery meaning is needed by involving both decoding and inferencing. In relevance theory, it is called rimplicature (Sperber \& Wilson, 1986). There are two kinds of r-implicature: implicated premises that refer to contextual assumptions intended by the speakers and supplied by the addressee; and implicated conclusion that is a contextual implication communicated by the speakers.

According to Sperber and Wilson, there are two qualities of r-implicature (Huang, 2012). The first, strong r-implicature that refers to the utterance 
proposition's recovery is essential to understand the speakers' intended meaning. Meanwhile, the second, weak r-implicature refers to the meaning recovery that is not needed because the utterance proposition is far away from the utterance context. Explicature or implicature needs to be based on relevance theory's communicative principle (Huang, 2012). Deciding the propositions of utterance from the meaning recovery should be on the speakers' and addressees' satisfaction.

Regarding the relevance theory, there are key points for interpreting the meaning and intention of implied and explicit utterance: constructing an appropriate hypothesis about explicit content via decoding, disambiguation, reference resolution, and other pragmatic enrichment processes; constructing an appropriate hypothesis about the intended contextual assumptions or implicated premises; and constructing an appropriate hypothesis about the intended contextual implications or implicated conclusions.

\subsection{Memes}

Dawkins in 1976 (as stated by Yus, 2018) was initially created the term of a meme, which refers to the idea of the disseminated cultural unit. Meme contains information that can influence people's minds by duplicating replicability or imitation embedded with culture. Moreover, Pech (2003, in Taecharungroj and Nueangjamnong, 2014) mentioned that meme conveys knowledge, views, perception, and beliefs. Hence, a meme is defined as units of information, ideas, mental representation, and cultural instruction. Then, it is communicated and spread from person to person or user to user through the internet. Hence it becomes internet memes (Yus, 2018). According to Dynel (2016), an internet meme is an artifact on the internet created by anyone by imitating, remixing, and diffusing through technology-mediated communication. Sagev and Shiftman (2015) added that a meme is a group of digital items with similar characteristics of content, form, and stance shared by users on the internet. The characteristics of the meme are cultural information, imitation, competition, and selection.

As defined above, a meme is not a single independent, pragmatic phenomenon in which it also contains cultural and social bounded, values, and linguistic features as a group. It means that one meme relates to other memes because of those items. It is easy to find similar memes on the internet because of meme families. One of the types of memes mentioned by Yus (2011) is a macro image meme, which becomes the researcher's concern. Image macro meme itself is made up of a line or two texts on the top and button and one picture in the middle. Those text-picture combinations of memes associate with a relevance theory to interpret the implication.
In understanding the text-picture combination of micro image memes, relevance theory must account for gaining pragmatic implication. Based on Sperber and Wilson's relevance theory (1986), Yus (2016) adopted explicature, referring to explicit interpretation and implicature to the implicit interpretation of verbal contents. Also, there are visual explicature and visual implicature (Forceville, 2014).

To get the whole comprehension of text-picture combination on memes, Yus (2018) highlighted some concepts. First, the meme users should make inferential hypotheses based on showed text and pictures. Second, the users need to infer the picture based on two qualities: denotative and connotative quality. A denotative quality or visual explicature (Forceville, 2014) refers to pictures providing relevant references without any further implications. Meanwhile, a connotative quality or visual implicature (Forceville, 2014) needs combinations between the picture and contextual information. Visual explicature is easy to interpret if the users know the related information because their mental references are already connected. Meanwhile, for visual implicature, the understanding concept requires contexts to make the picture relevant to users' hypotheses.

\subsection{Multimodality in Relevance Theory}

Communication on the internet provides discourses in various multimodality modes such as text, picture, audio, and video, according to Stökl (2009, as stated Yus, 2018). Yus (2018) stated that analyzing picturetext combinations leads to cyber-pragmatics, requiring all modes to integrate to make optimal relevance to yield implications. Thus, the relation among modes is the key to communication. It also happens in memes communication in which text and picture play essential roles in relevance theory.

In addition to text-picture combinations, McCloud (1994) proposed several categories for multimodal combination in comics which is also aligned with a textpicture combination on micro image memes. First, word specific which means pictures only illustrating not significantly contribute to the meaning. Second, picture specific refers to pictures dominating the meaning but words do not contribute significantly. Third, Duo specific as both words and pictures are essential to give meaning. Fourth, an additive combination refers to words that amplify the picture or vice versa. The fifth, parallel combination which is words and pictures are in different courses without intersecting. Sixth, montage combination which words are treated as integral parts of the picture. The last, interdependent in which words and pictures need each other to convey the meaning. 


\subsection{Humor}

Besides containing Pragmatic implications (Yus, 2018), a meme has humor following relevance theory (Yus, 2003; 2008; 2012). Yus (2012) stated that relevance theory could be an adequate theoretical framework to explain jokes in how they were designed and produce a humorous effect. Humor is defined by Reyes, Rosso,and Buscaldi (2012) as the presence of amusing effects such as laughter or well-sensations.

There are seven categories of humor, according to Catanescu and Tom (2001). First is comparison humor which putting two or more elements together to produce a humorous situation. The second is personification that attributes human characteristics to animals, plants, and objects. Third, exaggeration is overstating and magnifying something out of proportion. Fourth, pun refers to humor as a result of using elements of language to create new meanings. Fifth, sarcasm or blatant ironic responses or situations. Sixth is silliness as making funny faces to ludicrous situations. The last is a surprise as humor arises from unexpected situations. Further, Yus (2012) defines humor as a joke, and then he classified it into a taxonomy. Generally, there are two types of humor which are intentional and unintentional humor. Intentional humor is divided into two taxonomies: integrated with conversation which is based on the interpretation of explicit and implicit humor; and non-integrated in conversation which is based on social and cultural assumptions stored in the hearer's encyclopedia information.

Recently some studies have been conducted related to memes under relevance theory. Taecharungroj and Nueangjamnong (2014) conducted a study of internet memes on social media concerning the effect of humor on virality. Using the quantitative method and content analysis, the researchers found the relationship between humor styles, the number of likes and comments, and the memes' virality or the number of shares. Yus (2018) analyzed multimodality quality in memes based on a corpus of 100 instances of image macro meme to gain the relationship between picture and text combination and its impact on the eventual interpretation quality. Lynda and Idegbekwe (2020) conducted a study related to echoic communications and pragmatic relevance for analyzing Covid-19 memes in Nigeria's social media space. This study found that memes' interpretations were significantly linked with the shared cognitive background knowledge that the speaker/meme creator and the hearer/audience have.

This study differs from previous related researches because memes' analysis focuses on Indonesia's social phenomenon of memes as a response during the Covid19 pandemic. Moreover, each meme in this study was analyzed following several theories such as relevance, multimodality of text-picture combinations, verbal and visual explicature and implicature, and humor. The correlation relevance theory to this study's concern is because memes have implicit and explicit meaning based on text-picture combinations.

\section{METHOD}

To ensure the data taken are solid and valid, the research methodology is presented in the following section.

\subsection{Research Design}

This study was conducted using qualitative descriptive research to capture the social phenomenon of internet memes naturally. Nassaji (2015) mentioned that qualitative research is interpretative and naturalistic. $\mathrm{He}$ also stated that qualitative and interpretative deal with written text, image, audio, and video recorded. It is suitable for the data analysis since a text and picture combination on macro image meme was showed.

\subsection{Materials}

The researcher purposively collected five macro image memes on the internet. The reason only five memes are served is that the selected memes have already represented the related issues during the pandemic, such as self-quarantine, work from home, online class, online graduation, etc.

\subsection{Data Collection and Analysis}

For the data analysis, the researcher employed some steps. First, memes were analyzed using McCloud's (1994) categories for multimodal combination to explore what kind of text-picture combination and relationship contribute to the meaning. Second, they were interpreted based on Sperber and Wilson's relevance theory (1986) adapted by Yus' (2016) verbal explicature and implicature. Third, the memes were investigated following Forceville's theory (2014) of visual explicature and implicature interpretations. Fourth, the memes were presented and interpreted into the humor sense by following several categories, according to Yus (2012) and Catanescu and Tom (2001). Finally, they were concluded following the optimal relevance of Sperber and Wilson (1986) adapted by Yus (2016).

\section{FINDINGS AND DISCUSSION}

The discussions of the research findings are mentioned below following some issues during the pandemic situation.

The meme as shown in Figure 1 was appeared at the beginning of the Corona-virus attack. 


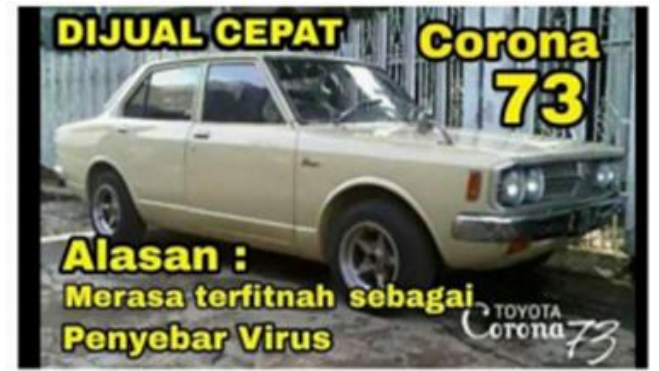

Figure 1 This meme was published by Tim Detik.Com. (2020) on Tuesday $28^{\text {th }}$ January 2020

Using Yus's theory of explicature (2016), this meme can be interpreted that Corona 73 as a type of Toyota car is being sold as soon as possible. Meanwhile, this meme's implied meaning is to give a humor sensation by comparing Toyota Corona 73 with Corona-virus when scientists, researchers, and experts, are looking for the cause of Corona-virus spreading. It is also aligned with what Catanescu and Tom (2001) meant as comparison humor.

Using Forceville's theory (2014), it can be seen that this meme contains visual implicature because understanding this meme needs combinations between the picture and contextual information. Users will not infer what Corona-73 is if there is no clear picture of a Toyota car type. Also, this kind of meme has an interdependent relationship between text and picture because the words on the top and button of meme and car picture contribute to the interpretation (McCloud, 1994).

The text-picture combination maximizes the cognitive and humor effect more than its processing effort because the verbal and visual explicature is relevant enough to users' existing information. It leads to optimal relevance meant by Wilson and Sperber (2002) and Yus (2006) that the text-picture combination helps users to link with their abilities and preferences of existing knowledge.

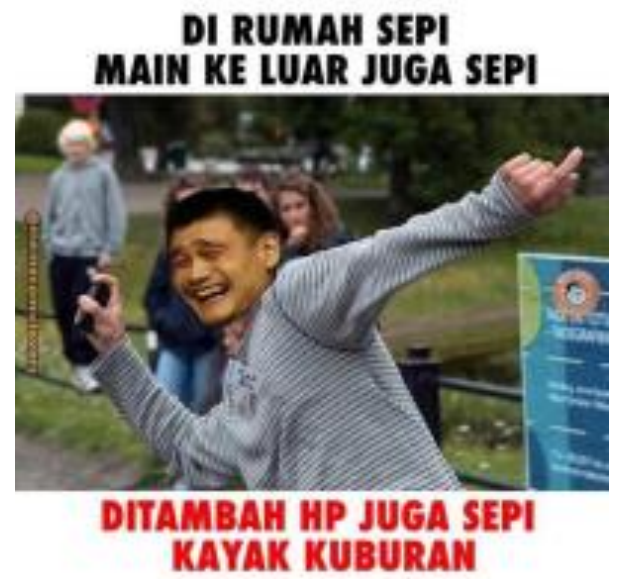

Figure 2 This meme was created by Abidin (2020) in beepdo.com in January 2020
Meme on Figure 2 is used to express people feeling when self-quarantine is required to do for Indonesians considering self-protection from the Corona-virus. People are forbidden to travel or go anywhere, which can trigger the virus to spread away, such as public space, workplace, schools, and many more. Furthermore, those who need to travel across regions should do self-quarantine. This situation leads to uncommon silence and emptiness.

Based on explicature and implicature interpretation (Yus, 2012; 2016), this meme informs the users that emptiness happens everywhere inside and outside the house and hand phone's notification. Further, this meme implicitly tells the users of feeling loneliness interpretation. On the point of Forceville (2014), this meme displays visual explicature in which the users can understand the contextual event, especially the humor from the explicit written text.

Regarding the text-picture combination, this meme holds word specific category of McCloud (1994) because the text plays more than the picture in giving meaning. Furthermore, in humor types coined by Catanescu and Tom (2001), this meme is categorized as silliness. It can be seen from making a funny face on the meme even though that is not the real one. Henceforth, this meme is included in Yus's jokes taxonomy (2012) humor based on the interpretation of explicit and implicit meaning rather than cultural-based. Moreover, because the explicit text and supported picture vividly trigger users' understanding, it makes this meme relevant to users' processing effort, abilities, and preferences (Wilson \& Sperber, 2002 in Yus, 2006).

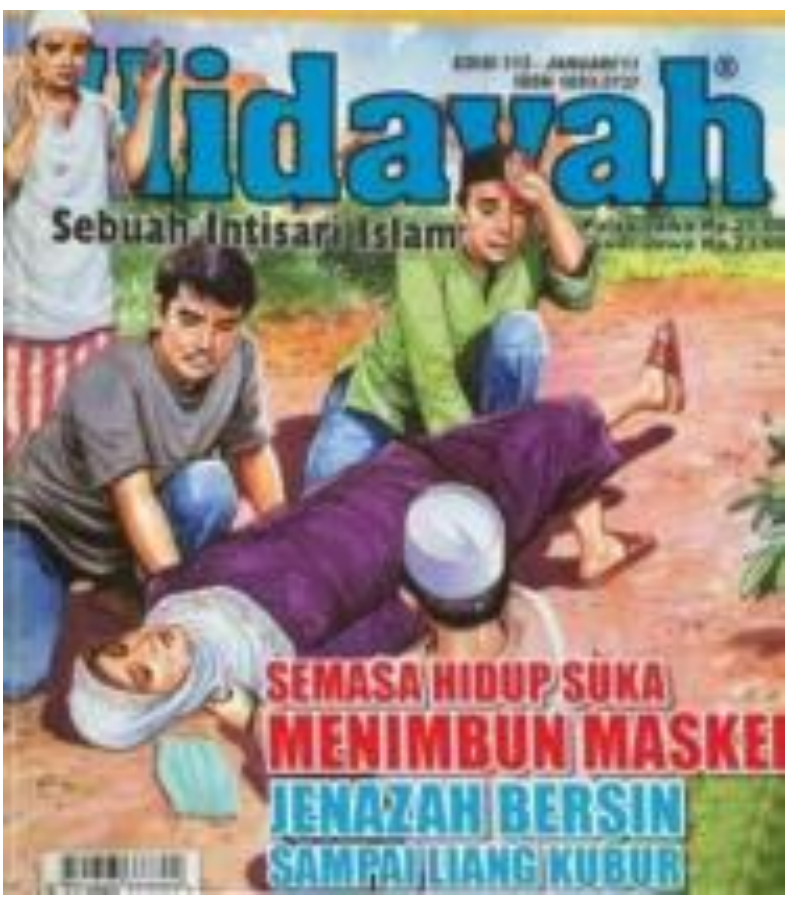

Figure 3 This meme was shared by by Gunadha, (2020) in suara.com on Thursday $5^{\text {th }}$ March 2020 
The contextual event of the meme on Figure 3 is describing the situation when Indonesians were panic to buy and wear a mask as what policymakers and doctors suggested for self-defense. Those who had more access and privilege could have and buy packs of masks, then became resellers to get more outcomes. This situation leads to a crisis because of panic-buyers.

Based on Yus's theory of explicature and implicature interpretation (2016), this meme explicitly states that people who keep masks into their benefits will get bad luck when they die. On the other hand, the implied meaning is to warn not to keep masks for getting benefits and offend mask keepers by hoping they get bad luck. Hence, it contains sarcasm humor as one of the types cited by Catanescu and Tom (2001) because of the offense.

This meme shows visual explicature in which users can clearly understand that it is a warning, not factual information. As stated by Forceville (2014) that visual explicature tells users the information even without necessarily involving their existing information because they have known the information and their mental references have already connected to the meme.

Further, the picture has visualized what is written on the meme. The text and pictures support each other to maximize and elaborate on the meme's meaning, especially on its illustration. It leads to an addictive text and picture combination, according to McCloud (1994), and optimal relevance (Wilson \& Sperber, 2002) because its processing effect is higher than the processing effort.

\section{UNBW3 2020 difledaken}

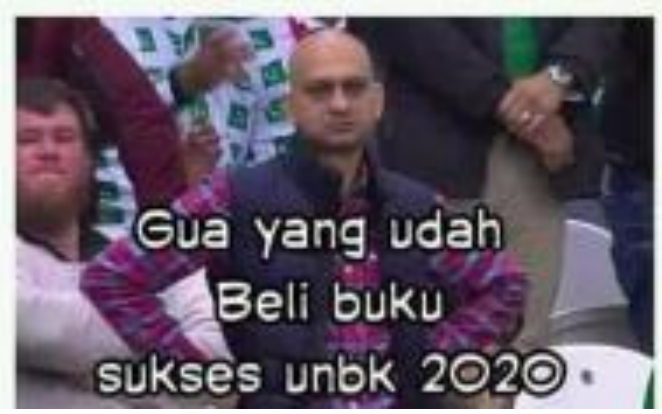

Figure 4 This meme was created by Aprilianto (2020) IDN Times on $26^{\text {th }}$ March 2020
The meme on Figure 4 was trending on Twitter when the Ministry of Education and Culture Indonesia decided to omit the national final exam because it was too risky to hold during the pandemic. Even though it was a big issue, the decision was so sudden. It was close to the final exam around April 2020 when school students already have prepared it.

Using Yus's theory (2016), this meme's verbal explicature interpretation only informs users that the national final exam was erased while a user (school students) has bought national final exam books. Using implicature interpretation, this meme shows the disappointment of a student who has prepared well for the national final exam but it is omitted. This ironic situation leads to implied humor (Yus, 2012) of sarcasm (Catanescu and Tom, 2001). Further, visual implicature (Forceville, 2014) is applied to this meme because users cannot understand what is shown if they do not know what is written. In the text picture combinations, this meme uses an additive category (McCloud, 1994) in which the words detailed picture and vice versa.

The Figure 5 meme became viral on social media, Twitter, and Instagram because many public figures posted their graduation pictures to support those who have online graduation due to the pandemic.

Following the explicature and implicature interpretation of Yus (2016), this meme's explicit verbal utterance tells online graduation limits users' interaction with others. Differently, in implicit verbal utterance, this meme expresses disappointment and unsatisfactory in a creative way. Besides, using Forceville's classification (2014), visual explicature is dominant in this meme rather than visual implicature because what is presented has already made users understand.

\section{Ketika wisuda diadakan online Atau mungkin ditiadakan.}

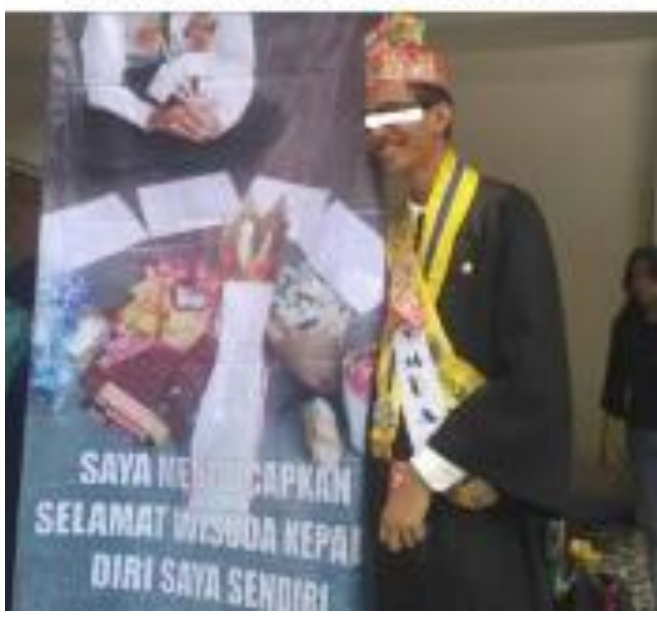

Figure 5 This meme was uploaded by Rizqi (2020) brilio.net on $10^{\text {th }}$ April 2020 
Word-specific category (McCloud, 1994) is used in this meme because the text has already described the meme, and the picture additionally illustrates it. Further, this meme has implied humor (Yus, 2012) even though it comes from an ironic situation. It is then relevant enough (Wilson \& Sperber, 2002 in Yus, 2006) to users' interpretation into sarcasm humor following Catanescu and Tom (2001).

\section{CONCLUSION}

It can be summed up that explicature and implicature interpretation towards verbal utterance and visual explicature and implicature make memes meet optimal relevance. Moreover, the text-picture combination used on the memes is useful to maximize the interpretation. Regarding humor, the memes give more humor effect if the memes are relevant enough to users' contextual information. Even though memes have different contextual events, using theoretical approaches of relevance as mentioned above contributes to relevant and comprehensive interpretations and implications.

\section{REFERENCES}

Abidin, K. (2020). Biar Nggak Bete Saat Mengisolasi Diri di Rumah, Simak Kumpulan Meme Lucu Ini Aja [Image]. Beepdo.com. Retrieved from: https://www.beepdo.com/94144/biar-nggak-betesaat-mengisolasi-diri-di-rumah-simak-kumpulanmeme-lucu-ini-aja/amp

Allott, N. (2013). Relevance theory. In Perspectives on linguistic pragmatics (pp. 57-98). Springer, Cham.

Aprilianto, M. B. (2020). Apa kabar yang udah beli buku Sukses UNBK 2020? Semoga gak nyesel, ya [Image]. IDN Times. Retrieved from: https://www.idntimes.com/hype/humor/muhamma d-bimo-aprilianto/meme-un-dibatalkan-inikocaknya-bikin-tambah-happy/8

Blakemore, D. (1992). Understanding utterances. Oxford: Blackwell.

Catanescu, C., \& Tom, G. (2001). Types of humor in television and magazine advertising. Review of Business-Saint Johns University, 22(1), 92-95.

Clark, B. (2013). Relevance theory. Cambridge University Press.

Detikcom. (2020). Meme Otomotif: Toyota Corona Dijual Cepat [Image]. Detik. Retrieved from: https://oto.detik.com/mobil/d-4876321/memeotomotif-toyota-corona-dijual-cepat

Dynel, M. (2016). "I has seen Image Macros!" Advice Animals memes as visual verbal jokes. International Journal of Communication, 10(29).
Forceville, C. (2014). Relevance Theory as model for analysing visual and multimodal communication. Visual communication, 4, 51. https://doi.org/10.1515/9783110255492.51

Grundy, P. (2013). Doing pragmatics. Routledge.

Gunadha, R. (2020). Meme Azab Penimbun Masker [Image]. Suara. Retrieved from https://www.suara.com/news/2020/03/05/175124/r amai-azab-penimbun-masker-sederet-meme-kocakbertebaran

Huang, Y. (2012). The Oxford Dictionary of Pragmatics. Oxford: University Press.

Lynda, C., \& Idegbekwe, D. (2020). Echoic Communications and Pragmatic Relevance of COVID 19 Memes in Nigeria's Social Media Space. Indian Journal of Language and Linguistics, 1(1), 19-30.

McCloud, Scott. (1994). Understanding Comics: The Invisible Art. New York: Harper Collins.

Nassaji, H. (2015). Qualitative and Descriptive Research: Data Type versus Data Analysis. Language Teaching Research, 19(2), 129-132. https://doi.org/10.1177/1362168815572747

Reyes, A., Rosso, P. \& Buscaldi, D. (2012). From Humor Recognition to Irony Detection: The Figurative Language of Social Media. Data \& Knowledge Engineering. 74. pp. 1-12.

Rizqi, T. (2020). Mengapresiasi diri sendiri itu penting. Teman-teman nggak bisa mampir, sih [Image]. Brilio.net. Retrieved from: https://www.brilio.net/ngakak/10-meme-wisudasaat-lockdown-ini-wakili-isi-hati-mahasiswa2004091.html

Segev, E., Nissenbaum, A., Stolero, N., \& Shifman, L. (2015). Families and Networks of Internet Memes: The Relationship between Cohesiveness, Uniqueness, and Quiddity Concreteness. Journal of Computer-Mediated Communication, 20(4), 417433.

Sperber, D., \& Wilson, D. (1986). Relevance: Communication and cognition (Vol. 142). Cambridge, MA: Harvard University Press.

Sperber, D., \& Wilson, D. (2004). Relevance theory. Handbook of Pragmatics. Oxford: Blackwell, $607-$ 632.

Taecharungroj, V., \& Nueangjamnong, P. (2014). The Effect of Humour on Virality: The Study of Internet Memes on Social Media. 7th International Forum on Public Relations and Advertising Media 
Impacts on Culture and Social Communication, 1, 151-166.

Yus, F. (2003). Humor and the search for relevance. Journal of Pragmatics, 35, 1295-1331.

Yus, F. (2006). Relevance theory. Encyclopedia of language and linguistics, 10, 512-519.

Yus, F. (2008). A Relevance-Theoretic Classification of Jokes. Lodz Papers in Pragmatics, 4(1), 131-157. https://doi.org/10.2478/v10016-008-0004-4

Yus, F. (2011). Strategies and effects in humorous discourse: The case of jokes. Linguistic Insights, $158,271-296$.
Yus, F. (2012). Relevance, humour and translation. Relevance Theory: More than Understanding. New Castle upon Tyne: Cambridge Scholars Publishing, 117- 145

Yus, F. (2016). Humour and Relevance (Vol. 4). Amsterdam: John Benjamins Publishing Company.

Yus, F. (2018). Multimodality in Memes: A cyber Pragmatic Approach. Analyzing Digital Discourse: New Insights and Future Directions (pp. 105-131). https://doi.org/10.1007/978-3-319-92663-6_4 